\title{
Biology and Management of Doveweed (Murdannia nudiflora) in Ornamental Crop Production ${ }^{1}$
}

\author{
Yuvraj Khamare, Chris Marble, Nathan Boyd, and Shawn Steed ${ }^{2}$
}

\section{Introduction}

Doveweed is a common grass-like warm-season annual weed in Florida landscapes, container nurseries, and other agricultural production systems. This article is written for green industry professionals and others to aid in the identification and management of doveweed in and around ornamental plants. Information on doveweed management in warm-season turfgrass species can be found at http:// edis.ifas.ufl.edu/pdffiles/AG/AG39500.pdf.

\section{Species Description}

\section{Class}

Monocot

\section{Family}

Commelinaceae-Spiderwort family

\section{Other Common Names}

Doveweed, nakedstem dewflower

\section{Life Span}

Warm-season annual

\section{Habitat}

Doveweed is a well-documented problem in landscape beds, turfgrass, and many agricultural crops. In container nurseries, doveweed grows in the potting soil of containergrown ornamentals, in drainage holes, or in walkways, aisles, ditches, and other areas that stay wet, such as lowlying areas or poorly drained soils.

\section{Distribution}

Doveweed is native to southern Asia and tropical Pacific regions but has been naturalized in tropical and subtropical regions of North America (Wagner et al. 1999). Doveweed has also naturalized in many areas of Africa, Oceania, Central and South America, and the West Indies. In the United States, doveweed can be found from North Carolina west to Texas and south to Florida (USDA-NRCS 2019). Occurrence of doveweed has been documented in 39 of 67 Florida counties (USDA-NRCS 2019; Wunderlin et al. 2019).

1. This document is ENH1312, one of a series of the Environmental Horticulture Department, UF/IFAS Extension. Original publication date September 2019. Visit the EDIS website at https://edis.ifas.ufl.edu for the currently supported version of this publication.

2. Yuvraj Khamare, graduate research assistant; Chris Marble, assistant professor, Environmental Horticulture Department, UF/IFAS Mid-Florida Research and Education Center; Nathan Boyd, associate professor, Horticultural Sciences Department, UF/IFAS Gulf Coast Research and Education Center; and Shawn Steed, multi-county environmental horticulture Extension agent III, UF/IFAS Extension Hillsborough County; UF/IFAS Extension, Gainesville, FL 32611.

The use of trade names in this publication is solely for the purpose of providing specific information. UF/IFAS does not guarantee or warranty the products named, and references to them in this publication do not signify our approval to the exclusion of other products of suitable composition. All chemicals should be used in accordance with directions on the manufacturer's label.

The Institute of Food and Agricultural Sciences (IFAS) is an Equal Opportunity Institution authorized to provide research, educational information and other services

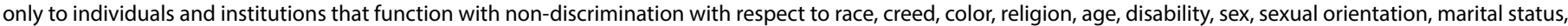

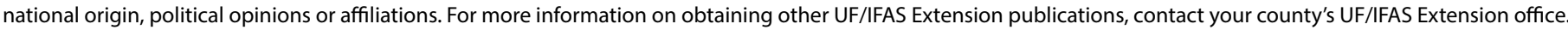
U.S. Department of Agriculture, UF/IFAS Extension Service, University of Florida, IFAS, Florida A \& M University Cooperative Extension Program, and Boards of County Commissioners Cooperating. Nick T. Place, dean for UF/IFAS Extension. 


\section{Growth Habit}

Doveweed is usually a low-growing, creeping annual with leafy or succulent branches. Stems may be either erect (upright) or semi-erect up to 12 inches tall, but doveweed usually does not reach this height (Figure 1). Doveweed forms dense mats by rooting along its nodes when the nodes are in contact with the soil.

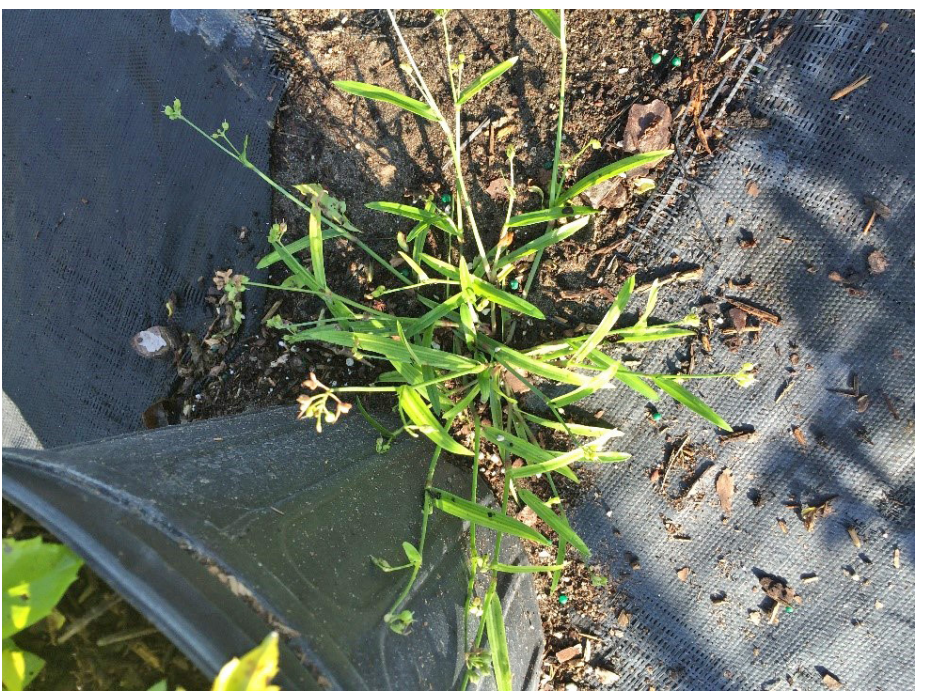

Figure 1. Doveweed plant growing through torn weed fabric. Credits: Annette Chandler, UF/IFAS

\section{Seedling}

Germination begins during the onset of warm and wet weather, typically around April or May in Florida, and continues throughout the summer. The leaves of young plants grow in a circular arrangement (rosette). The creeping stems are succulent, root along the nodes, and are grass-like. (Figure 2)

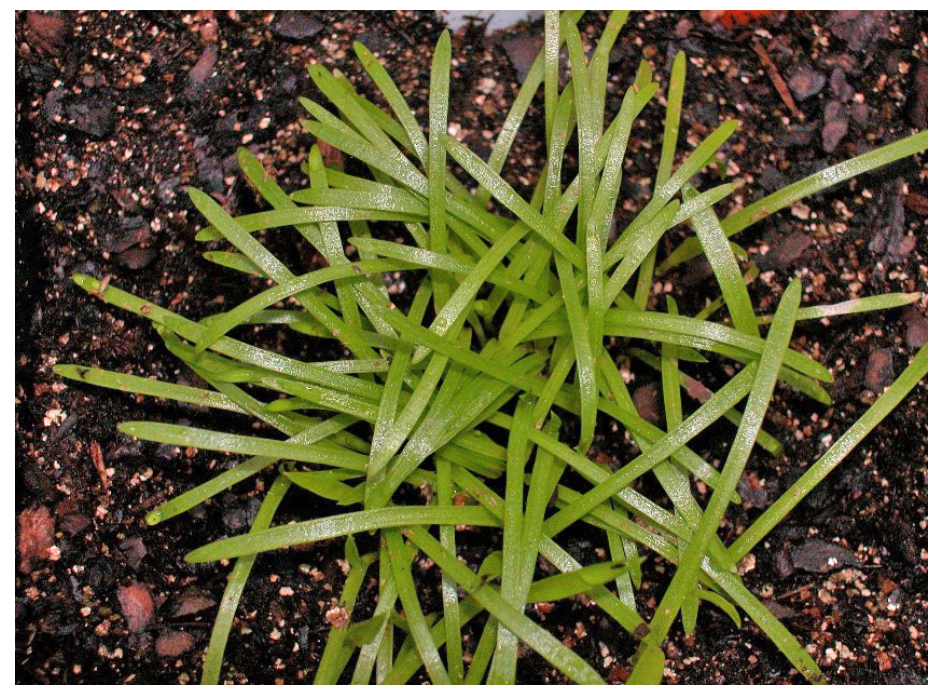

Figure 2. Grass-like doveweed seedling.

Credits: Annette Chandler, UF/IFAS

\section{Shoots}

The stems of the plant may not be visible, especially when growing in a dense mat. However, the stems are succulent, round, and smooth, and they root extensively along the nodes. The stems may be purplish to reddish in color (Figure 3). The leaves have parallel venation and are 2 to 5 inches long, 0.25 to 0.5 inches wide, narrow, pointed, spirally arranged, and clasp the stem (Figure 4). When young, doveweed is often misidentified as a grass. Leaf sheaths have soft hairs on the upper margins. Doveweed shoots often have a shiny appearance compared to other weed species.

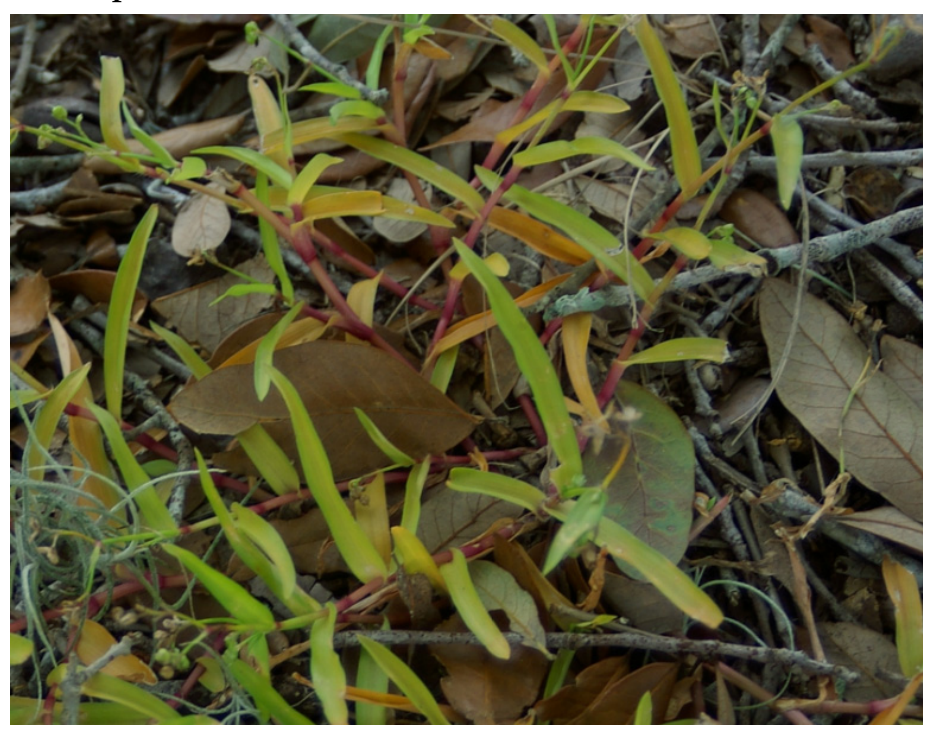

Figure 3. Doveweed stems. Note-the creeping stems resemble a grass.

Credits: Annette Chandler, UF/IFAS

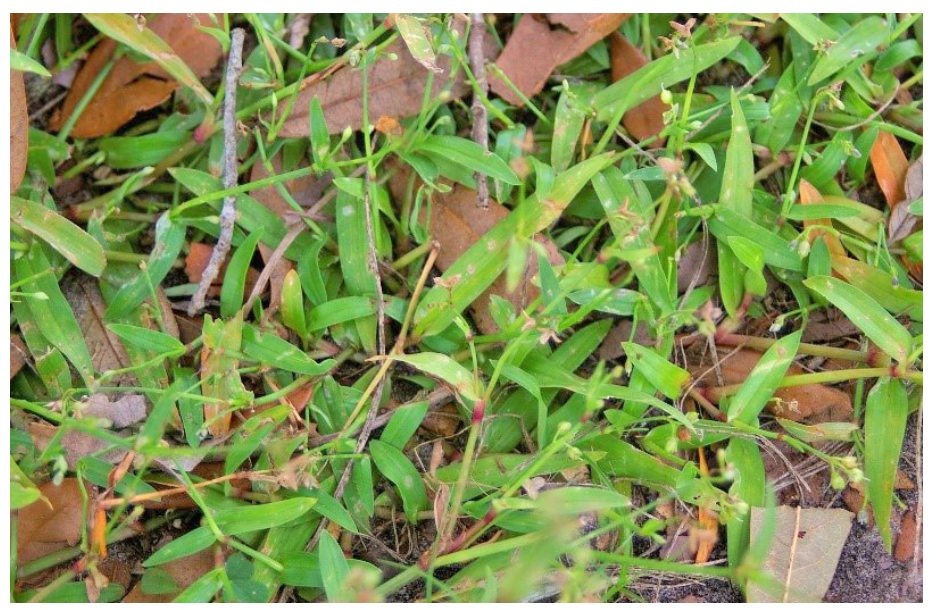

Figure 4. Doveweed leaves.

Credits: Annette Chandler, UF/IFAS

\section{Roots}

Doveweed has a fibrous root system comprised of thin roots that are white to brown in color. The roots emerge from the nodes and may be hairy (Figure 5). 


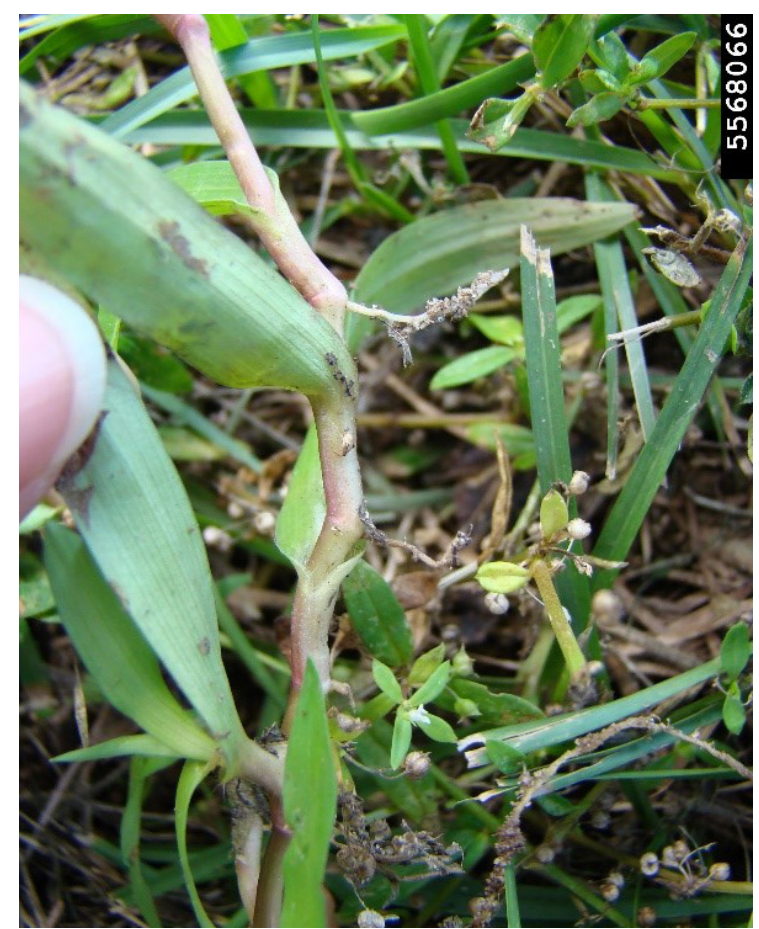

Figure 5. Doveweed roots. Note-roots are growing on nodes. Credits: Rebekah D. Wallace, University of Georgia, Bugwood.org

\section{Inflorescence}

The flowers are stalked and form in small clusters from midsummer throughout the fall. They are short-lived, in terminal or axillary long-stalked inflorescences (Figure 6). Flowers are blue or purple in color with 3 sepals and 3 petals that are 0.2 to 0.5 inches long. It has three to four sterile stamens (pollen-bearing organ of a flower) with long bearded filaments and bluish-colored anthers.

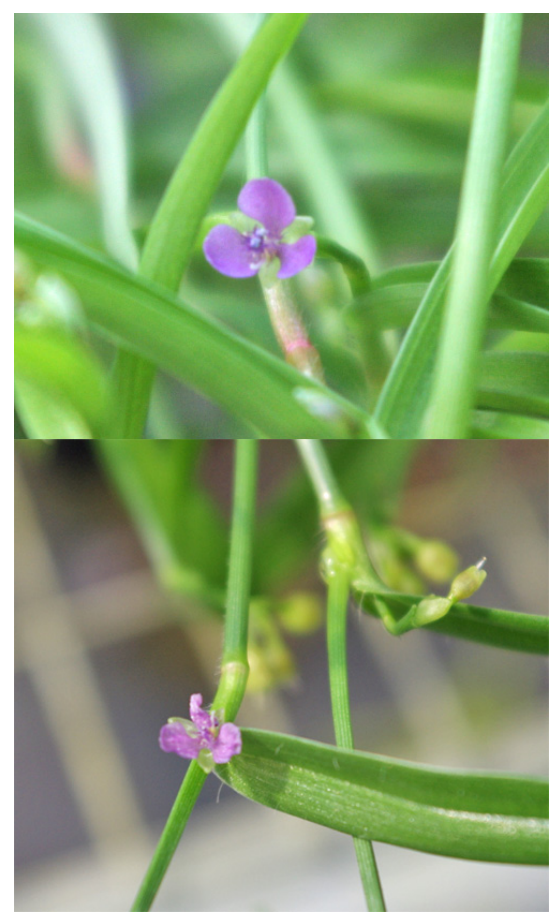

Figure 6. Doveweed flowers.

Credits: Annette Chandler, UF/IFAS

\section{Fruit and Seeds}

The fruit is a condensed capsule that is glabrous and tapered at the end. The fruit is spherical or egg-shaped (ovoid-globose) and 0.1 to 0.2 inches wide. Fruit has 3 locules (segments) with one to two seeds in each segment. Seeds are dark brown, smooth to coarse in texture, subtriangular, and covered with tubercles (wart-like pieces). Seeds are mainly dispersed by wind, water, animals grazing, and fecal droppings of animals or during tillage. It reproduces by both seed and by forming roots along the shoots.

\section{Similar Species}

Murdannia nudiflora is similar in appearance to the Asiatic dewflower (Murdannia spirata) and can be mistakenly identified as the common dayflower (Commelina diffusa) (CABI 2019). Both of these species typically have much larger inflorescences and wider leaf blades than doveweed. In addition, these species grow much larger, and common dayflower is typically more vigorous (Soerjani et al. 1987). Marsh dayflower (Murdannia keisak) is another similar species but is less common in nurseries. Marsh dayflower is also larger and more vigorous than doveweed (Neal and Derr 2005).

\section{Plant Biology}

Seeds usually germinate when soil temperatures reach $65^{\circ} \mathrm{F}$ to $70^{\circ} \mathrm{F}$ late in the spring, with peak germination usually occurring when temperatures reach over $80^{\circ} \mathrm{F}$ (Wilson et al. 2006) during late April and May in Florida as temperatures and rainfall increase. Light is required for germination, and germination may be reduced by over $90 \%$ when seeds are covered by 1 inch or more in the soil (Ahmed et al. 2017). When mature, each plant can produce 500 to 2000 seeds, which are immediately viable but may remain dormant until the following year when conditions are ideal for germination. The plant flowers and dies following frost in the fall/winter. Doveweed is categorized as one of the world's worst weeds (Holm et al. 1977) due to its ability to root easily along the nodes and adapt and survive in a wide range of soil types and environments.

\section{Management \\ Physical and Cultural Control}

Doveweed is becoming a more common weed in container nurseries and has been a problematic species in landscapes and other cropping systems in the southeastern United States for many years (Walker et al. 2010). It thrives in wet areas, so correcting drainage issues and irrigating properly can help prevent the spread of doveweed (Leon and Unruh 
2015). Mulch applied at depths of 1 to 3 inches can be used in container-grown ornamentals or in landscape beds to prevent or reduce doveweed growth and germination. It is usually easy to hand-pull, but small stem fragments left behind have the ability to regrow. Because doveweed is a low-growing plant, mowing is usually not an effective management approach, but hand-weeding can be effective.

\section{Chemical Control}

\section{PREEMERGENCE}

Doveweed is typically much easier to manage with preemergence herbicides compared to postemergence herbicides (Stamps and Chandler 1999; Walker et al. 2010). In nurseries, granular herbicides, including flumioxazin (Broadstar ${ }^{\circledR}$ ), pendimethalin + dimethenamid-P (FreeHand ${ }^{\circledR}$ ), or indaziflam (Marengo ${ }^{\circledR} \mathrm{G}$ ), or spray-applied herbicides, such as dimethenamid-P (Tower ${ }^{\circledR}$ ) or $S$-metolachlor (Pennant Magnum ${ }^{\circledR}$ ), can be used for preemergence control of doveweed and can be applied over-the-top of labeled ornamental species to control doveweed in containers. These herbicides can also be used in landscape beds; however, Specticle ${ }^{\circledR} \mathrm{G}$ is the trade name for indaziflam labeled for use in landscapes. In bareground areas or in situations where a directed application is needed (applied to avoid contact with the crop), spray-applied herbicides such as SureGuard ${ }^{\circledR}$ (flumioxazin) or Marengo ${ }^{\circledR}$ SC/Specticle ${ }^{\circledR}$ FLO (indaziflam) can be used. Efficacy rankings and labeled uses for other preemergence herbicides are included in Table 1.

\section{POSTEMERGENCE}

Most postemergence herbicides recommended for controlling doveweed are not labeled for use in container nurseries or in landscape planting beds. Nonselective herbicides such as glyphosate (many trade names available) or glufosinate (Finale ${ }^{\circledR}$ ) can be used as a directed or spot application (avoiding ornamental plant foliage, stems, etc.) in planting beds, but multiple applications may be required depending upon plant size. Contact herbicides such as diquat (Reward ${ }^{\circledR}$ ) or Scythe ${ }^{\circledR}$ (pelargonic acid) can also be used to control small doveweed plants.

\section{References}

Ahmed, S., J. L. Opena, and B. S. Chauhan. 2017. "Seed Germination Ecology of Doveweed (Murdannia nudiflora) and Its Implication for Management in Dry-Seeded Rice." Weed Sci. 63:491-501.
CAB International (CABI). 2019. "Murdannia nudiflora (doveweed).” https://www.cabi.org/isc/datasheet/35180

Holm, L. R., D. L. Plucknett, J. V. Panco, and J. P. Herberger. 1977. The World's Worst Weeds: Distribution and Biology. University Press of Hawaii Honolulu, USA.

Leon, R. G., and B. Unruh. 2015. Doveweed (Murdannia nudiflora) Control in Warm-Season Turfgrass Species. SS-AGR-391. Gainesville: University of Florida Institute of Food and Agricultural Sciences. http://edis.ifas.ufl.edu/ pdffiles/AG/AG39500.pdf

Neal, J. C., and J. F. Derr. 2005. Weeds of Container Nurseries in the United States. Raleigh, NC: North Carolina Assoc. of Nurserymen, Inc.

Soerjani, M., A. J. G. H. Kostermans, and G. Tjitrosoepomo. 1987. Weeds of Indonesia. Jakarta, Indonesia: Balai Pustaka.

Stamps, R. H., and A. L. Chandler. 1999. "Doveweed, Florida Tasselflower, and Eclipta Control under Heavy Rainfall Conditions Using Granular Preemergence Herbicides." Proceedings of the Southern Nurseryman's Association Research Conference. 50: 435-439.

USDA-NRCS. 2019. "Plants Profile for Murdannia nudiflora (nakedstem dewflower)." https://plants.usda.gov/core/ profile? symbol=MUNU

Wagner, W. L., D. R. Herbst, and S. H.Sohmer. 1999. Manual of the Flowering Plants of Hawaii. Volumes 1 and 2. Honolulu, HI: University of Hawaii and Bishop Museum Press.

Walker, L. C., J. C. Neal, and J. F. Derr. 2010. "Preemergence Control of Doveweed (Murdannia nudiflora) in ContainerGrown Nursery Crops.” J. Environ. Hort. 28: 8-12.

Wilson, D. G., M. G. Burton, J. F. Spears, and A. C. York. 2006. "Doveweed (Murdannia nudiflora) Germination and Emergence as Affected by Temperature and Seed Burial Depth." Weed. Sci. 54: 1000-1003.

Wunderlin, R. P., B. F. Hansen, A. R. Franck, and F. B. Essig. 2019. "Atlas of Florida Plants." http://florida.plantatlas.usf. edu 
Table 1. Preemergence herbicides labeled for use in ornamental plant production and landscapes to control doveweed.

\begin{tabular}{|c|c|c|c|c|c|c|c|}
\hline $\begin{array}{c}\text { Common name (active } \\
\text { ingredient) }\end{array}$ & $\begin{array}{l}\text { Example trade name and } \\
\text { formulation }\end{array}$ & $\begin{array}{l}\text { WSSA } \\
\text { Herbicide } \\
\text { Group' }\end{array}$ & Efficacy $^{2}$ & $\begin{array}{l}\text { Container } \\
\text { production }\end{array}$ & $\begin{array}{c}\text { Field } \\
\text { production }\end{array}$ & $\begin{array}{l}\text { Greenhouse or } \\
\text { fully enclosed } \\
\text { structures }\end{array}$ & Landscape \\
\hline dithiopyr & Dimension ${ }^{\circledR} 2 \mathrm{EW}$ & 3 & $\mathrm{P}$ & YES & YES & NO & YES \\
\hline \multirow[t]{2}{*}{ pendimethalin } & Pendulum ${ }^{\circledR} 2 \mathrm{G}$ & \multirow[t]{2}{*}{3} & \multirow[t]{2}{*}{$\mathrm{P}$} & YES & YES & NO & YES \\
\hline & Pendulum ${ }^{\circledR} 3.3 \mathrm{EC}, 3.8 \mathrm{AC}$ & & & YES & YES & NO & YES \\
\hline prodiamine & Barricade ${ }^{\circledR} 4 \mathrm{FL}, 65 \mathrm{WG}$ & 3 & $P$ & YES & YES & NO & YES \\
\hline trifluralin & Treflan $^{\circledR} 5 \mathrm{G}$ & 3 & $P$ & YES & YES & NO & YES \\
\hline simazine & Simazine 4L & 5 & C & YES & YES & NO & YES \\
\hline \multirow[t]{2}{*}{ flumioxazin } & Broadstarm $^{\mathrm{TM}} 0.25 \mathrm{G}$ & \multirow[t]{2}{*}{14} & \multirow[t]{2}{*}{ C } & YES & YES & NO & YES \\
\hline & SureGuard ${ }^{\circledR} 51$ WDG & & & $\mathrm{YES}^{3}$ & $\mathrm{YES}^{3}$ & $\mathrm{YES}^{4}$ & $\mathrm{YES}^{5}$ \\
\hline dimethenamid-p & Tower ${ }^{\circledR}$ 6EC & 15 & C & YES & YES & NO & YES \\
\hline S-metolachlor & Pennant Magnum ${ }^{\circledR} 7.6 \mathrm{EC}$ & 15 & C & YES & YES & NO & YES \\
\hline isoxaben & Gallery ${ }^{\circledR} 75 \mathrm{DF}, 4.16 \mathrm{SC}$ & 21 & $P$ & YES & YES & NO & YES \\
\hline \multirow[t]{4}{*}{ indaziflam } & Specticle ${ }^{\circledR} 0.622$ FLO & \multirow[t]{4}{*}{29} & \multirow[t]{4}{*}{ C } & NO & NO & NO & YES \\
\hline & Specticle ${ }^{\circledR} 0.0224 G$ & & & NO & NO & NO & YES \\
\hline & Marengo ${ }^{\circledR} 0.622 \mathrm{SC}$ & & & $\mathrm{NO}^{6}$ & YES & $\mathrm{YES}^{7}$ & NO \\
\hline & Marengo ${ }^{\circledR} 0.0224 \mathrm{G}$ & & & YES & YES & NO & NO \\
\hline $\begin{array}{l}\text { pendimethalin }+ \\
\text { dimethenamid-p }\end{array}$ & FreeHand ${ }^{\circledR} 1.75 \mathrm{G}$ & $3+15$ & $\mathrm{~S}-\mathrm{C}$ & YES & YES & NO & YES \\
\hline trifluralin + isoxaben & Snapshot ${ }^{\circledR} 2.5 \mathrm{TG}$ & $3+21$ & $P$ & YES & YES & NO & YES \\
\hline prodiamine + isoxaben & Gemini $^{\mathrm{TM}} 3.7 \mathrm{SC}$ & $3+21$ & $\mathrm{P}$ & YES & YES & NO & NO \\
\hline oxyfluorfen + oryzalin & Rout ${ }^{\circledR} 3 G$ & $14+3$ & $\mathrm{~S}$ & YES & YES & NO & YES \\
\hline $\begin{array}{l}\text { oxyfluorfen + } \\
\text { pendimethalin }\end{array}$ & $\mathrm{OH} 2{ }^{\circledR} 3 \mathrm{G}$ & $14+3$ & $S$ & YES & YES & NO & YES \\
\hline oxyfluorfen + prodiamine & Biathlon ${ }^{\circledR} 2.75 \mathrm{G}$ & $14+3$ & $S$ & YES & YES & NO & YES \\
\hline \multicolumn{8}{|c|}{ 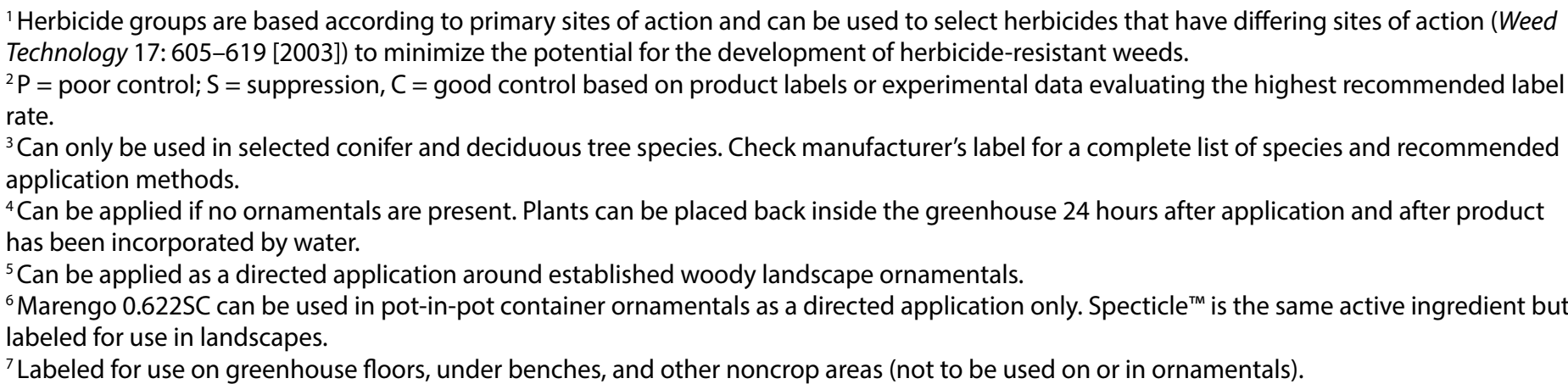 } \\
\hline
\end{tabular}

